Вісник ЛНУ імені Тараса Шевченка № 2 (325), 2019

УДК 378.091'81'243

doi: 10.12958/2227-2844-2019-2(325)-361-370

\title{
Морозова М.В.
}

margaritaveremeeva@gmail.com

https://orcid.org/0000-0002-7478-2530

викладач, кафедра романо-германської філології, Д3 «Луганський національний університет

імені Тараса Шевченка»

Полтава, Україна

\section{ОРГАНІЗАЦІЯ СУБ'ЄКТ-СУБ'ЄКТНОЇ ВЗАСМОДІЇ В СИСТЕМІ ВЗАСМОВІДНОСИН „ВИКЛАДАЧ - МАЙБУТНІ ВЧИТЕЛІ” В ПРОЦЕСІ ВИВЧЕННЯ ІНОЗЕМНИХ МОВ}

У сучасній освіті затверджується пріоритет особистості майбутнього вчителя іноземних мов не як абстрактного об'єкта впливу, а як головного суб'єкта в особистісному та громадському вимірах освіти. Однією 3 важливих умов ефективного освітнього процесу постає взаємодія його суб'єктів. Майбутній учитель сьогодні розглядається як суб'єкт освітніх змін, співучасник педагогічного процесу, творча особистість, а не як об'єкт зовнішніх впливів чи натисків. Успішність організації суб'єкт-суб'єктної взаємодії при вивченні іноземних мов залежить від багатьох чинників: від правильного вибору теоретичного підходу і технології суб'єкт-суб'єктної взаємодії; від ефективності використовуваних механізмів, педагогічних методів; від системності аналізу та вирішення педагогічних і особистісних проблем.

Дослідження процесу організації суб'єкт-суб'єктної взаємодії викладача і майбутні вчителів іноземних мов репрезентовано в працях провідних вчених в педагогічній діяльності (К. Абульханової-Славської, О. Анісімова, А. Деркач, О. Ліннік, В. Петровського), в психології (Б. Ананьєв, А. Брушлинский, І. Зимня, С. Рубінштейн, В. Слободчиков), в методиці викладання іноземних мов (С. Ніколаєва, Л. Панова, С. Потапенко, О. Соловова, Г. Чекаль), та ін.

Проте проблема організації суб'єкт-суб'єктної взаємодії в системі взаємовідносин „викладач - майбутні вчителі” при вивченні іноземних мов $\epsilon$ не достатньо освітленою та залишається предметом дискусій багатьох вчених. Багатовекторність освітнього процесу вимагає ретельного підходу до особливостей організації суб'єкт-суб'єктної взаємодії викладача і майбутніх учителів іноземних мов.

Метою статті $\epsilon$ теоретичне обгрунтування процесу організації суб'єкт-суб'єктної взаємодії в системі взаємовідносин „викладач майбутні вчителі" при вивченні іноземних мов.

Для досягнення поставленої мети необхідно розв'язати наступні завдання: 1) схарактеризувати особливості організації суб'єктсуб'єктної взаємодії в процесі вивчення іноземних мов; 2) визначити 
види взаємовідносин при організації суб'єкт-суб'єктної взаємодії в системі „викладач - майбутні вчителі”.

У процесі вивчення іноземних мов найважливішою характеристикою організації суб'єкт-суб'єктної взаємодії $\epsilon$ стиль педагогічного спілкування, тобто індивідуальні особливості взаємодії викладача і майбутнього вчителя. Як стверджує О. Гончар, на практиці найбільше значення надається класичним стилям взаємодії:

- Авторитарний стиль. Авторитарний викладач одноосібно визначає напрям діяльності групи, указує, хто 3 ким повинен сидіти, працювати, припиняє будь-яку ініціативу майбутніх учителів. Основні форми взаємодії- наказ, указівка, інструкція, догана. Викладач лаконічний, у нього переважає начальницький тон, нетерпіння до заперечень. Авторитарний стиль забезпечує уявну ефективність діяльності, але за відсутності викладача робота сповільнюється, а то й зовсім припиняється. Цей стиль створює несприятливий психологічний клімат. При такому стилі затримується становлення всіх якостей особистості.

- Ліберальний стиль - анархічний, безконтрольний. Ліберальний викладач прагне не втручатися в життя колективу, не проявляє активності, питання розглядає формально, легко підкоряється іншим суперечливим впливам. Він самоусувається від відповідальності за те, що відбувається. Про авторитет мовлення також не може й бути розмови. Цей стиль $\epsilon$ найгіршим стилем керівництва, при ньому робота зазвичай виконується менше і якість їі гірше.

- Демократичний стиль. Демократичний викладач спирається на думку колективу, він намагається донести мету діяльності до свідомості кожного, намагається найбільш оптимально розподілити навантаження, ураховуючи індивідуальні схильності й здібності. Основні способи спілкування в такого викладача - це прохання, порада та інформація. Викладач поважає думку майбутніх учителів іноземних мов. Хоча кількісні показники тут можуть бути i нижче, ніж при авторитарному, але бажання працювати не вичерпується й під час відсутності педагога. Підвищується творчий тонус, розвивається почуття відповідальності та гордості за свій колектив. Цей стиль $є$ найбільш прийнятним у будь-якому навчальному закладі [Гончар 2011: 52].

Сьогодні найбільшу перевагу віддається демократичному стилю, хоча й інші стилі використовуються. У різних ситуаціях при вивченні іноземних мов усі стилі можуть стати оптимальними, а суб'єктам взаємодії потрібно бути гнучкими в їх застосуванні. Л. Петухова вказує, що різні стилі знаходять відображення в різних моделях взаємодії, описаних на заняттях з іноземних мов:

Модель 1. Викладач немовби підноситься над майбутніми учителями; він відсторонений від них, мало цікавиться ними; йому важливий лише процес повідомлення інформації. Негативні наслідки 
такої поведінки - відсутність контакту між викладачем і майбутніми вчителями.

Модель 2. Викладач дистанціюється від майбутніх учителів іноземних мов, підкреслює перевагу над ними, не досягає активної взаємодії. Небажані наслідки - відсутність міжособистісного контакту між викладачем і майбутніми вчителями, слабкий відповідний зв'язок, байдужість до викладача з боку майбутніх учителів.

Модель 3. Викладач будує взаємодію 3 майбутніми вчителями вибірково, як локатор; непоєднуваний індивідуальний підхід із фронтальним. У результаті йому не вдається створити цілісну систему взаємодії.

Модель 4. Викладач чує тільки себе, поглинений своїми завданнями і думками, неуважний до майбутніх учителів іноземних мов. Внаслідок цього втрачається зворотний зв'язок, погіршується психологічний клімат.

Модель 5. Викладач діє строго за наміченим планом, не враховуючи мінливі обставини. У результаті розходяться ідеальна та реальна лінії взаємодії.

Модель 6. Викладач поводиться як головний суб'єкт, припиняючи ініціативу майбутніх учителів. У результаті знижується активність майбутніх учителів, взаємодія слабшає, а пасивність майбутніх учителів зростає.

Модель 7. Викладач не впевнений у собі, відчуває сумніви у своїх здібностях успішно взаємодіяти 3 майбутніми вчителями. Перебільшуючи значення взаємин 3 майбутніми вчителями, викладач послаблює увагу до змісту заняття.

Модель 8. Викладач дотримується дружнього стилю взаємодії 3 майбутніми вчителями, створює атмосферу спільної співпраці. Завдяки цьому взаємини будуються на взаємній повазі, співучасті, взаєморозуміння, що дає можливість успішної самореалізації й особистісного розвитку всіх учасників освітнього процесу [Петухова 2014: 77].

Охарактеризовані моделі взаємодії, за винятком восьмої, свідчать про те, що в реальному педагогічному процесі присутні негативні моменти, які пов'язані 3 професійно-особистісними особливостями викладачів і вимагають корекції.

На нашу думку, одним із важливих шляхів вдосконалення взаємодії викладачів і майбутніх учителів може бути більш повна, ніж на даний час, реалізація суб'єкт-суб'єктного підходу в процесі вивчення іноземних мов. Це передбачає й більш широку структуру взаємодії, що включає всі підструктури в системі суб'єкт-суб'єктної взаємодії учасників освітньої активності. Ось перелік необхідних структурних компонентів суб'єкт-суб'єктної взаємодії при вивченні іноземних мов: взаємодія у сфері стимулювання й мотивації; взаємодія в постановці цілей і завдань; взаємодія в проектуванні, плануванні та програмуванні; 
Вісник ЛНУ імені Тараса Шевченка № 2 (325), 2019

спільне прогнозування результатів; інформаційна підготовка до взаємодії; прийняття суб'єктами оптимальних спільних рішень; спільна практична організація взаємодії; спільний контроль і оцінка ходу, а також результатів взаємодії; спільне визначення перспектив та необхідних інновацій.

Конкретні технології реалізації суб'єкт-суб'єктної взаємодії в роботі $з$ майбутніми вчителями, безсумнівно, мають свою специфіку. А. Бойко пропонує різні підходи до організації суб'єкт-суб'єктної взаємодії в процесі вивчення іноземних мов:

- $\quad$ діяльнісний (має на меті формування у майбутніх учителів різноманітних способів і видів діяльності. Під діяльнісним підходом розуміють такий спосіб організації навчально-пізнавальної діяльності майбутніх учителів, при якому вони $є$ не пасивними „приймачами” інформації, а самі активно беруть участь у навчальному процесі);

- особистісно зорієнтований (забезпечує самопізнання, розвиток рефлексивних здібностей, оволодіння способами саморегуляції, самовдосконалення, самовизначення, формування життєвої позиції);

- $\quad$ акмеологічний (зоріснтований на цілісний i сталий розвиток освітніх систем та суб'єктів освітнього процесу в умовах творчої діяльності. Викладач і майбутній учитель, перебуваючи у творчій взаємодії й співпраці, забезпечують успіх один одному у своїй самореалізації);

- $\quad$ аксіологічний (має на меті впровадження у світ цінностей і надання їм допомоги у виборі особистісно значущої системи ціннісних орієнтацій);

- $\quad$ системний (підхід, при якому будь-яка система (об'єкт) розглядається як сукупність взаємопов'язаних компонентів, що має на меті ресурси, зв'язок із зовнішнім середовищем, зворотний зв'язок). [Бойко 2012: 9].

У широкому сенсі система взаємин „викладач - майбутні вчителі” має певну специфіку у сфері освіти: вона володіє особливою структурою, у якій чітко виділяються два основних структурних елементи, утворених одиничним суб'єктом і колективним суб'єктом, між якими існують суб'єкт-суб'єктні відносини. Двохелементний характер системи „викладач - майбутні вчителі” передбачає два типи внутрішніх базових відносин, що сприяють організації суб'єкт-суб' єктної взаємодії в процесі вивчення іноземних мов. При організації суб'єкт-суб'єктної взаємодії в системі „викладач - майбутні вчителі” пропонуємо шість видів відносин, які є усвідомлюваними і гармонійними в процесі вивчення іноземних мов.

1-й тип „від майбутнього вчителя” містить три види взаємин:

1 - „Я як суб'єкт - викладач”. Саме на цьому типові взаємин, перш за все, зроблено акцент у рамках особистісно зорієнтованої парадигми і в руслі концепції розвивальної освіти. Кожен викладач знає, що майбутній учитель взаємодіє з ним, перебуваючи сам на сам, часто 
зовсім інакше, ніж у присутності своїх одногрупників. Це відбувається тому, що в першому випадку він постає в якості окремого незалежного суб'єкта, а в другому - орієнтується на себе як члена спільноти (у наведеному прикладі - явно асоціального).

2 - „Я як частина групи (Ми з одногрупниками) - викладач”. При цьому викладач може розглядатися групою у двох аспектах: або як самостійний суб'єкт, або як представник професійно-педагогічної спільноти. I в тій, і в тій ситуації викладач розглядається майбутніми вчителями як протиставлений групі, однак $\epsilon$ „своїм”, а не „чужим”.

3 - „Я як частина всієї спільності „викладач - майбутні вчителі” (Ми разом із викладачем) - Вони”. У цьому випадку майбутній учитель іноземних мов ідентифікується не просто з групою своїх одногрупників: він включає в значущу для себе спільність і педагога. Тут категорія „Ми” виявляється найбільш широкою 3 усіх описуваних. „Вони” - це спільності, які можуть розглядатися як дружні, ворожі, конкурентні і т.п. Найчастіше під „Вони” в навчальному закладі маються на увазі групи, які можуть розглядатися як у чомусь пов'язані або чимось не пов'язані 3 „Ми” цілісністю.

2-й тип „від викладача”, також включає три види взаємин:

1 - „Я як суб'єкт - майбутній учитель іноземних мов”. У викладача так чи інакше складаються певні стосунки 3 кожним майбутнім учителем. Він може глибоко усвідомлювати особливості цих взаємин у взаємодії або зовсім не замислюватися над цим, але практично завжди міжособистісний простір між ним і кожним конкретним його майбутнім учителем насичений емоційними, когнітивними, смисловими, ціннісними та іншими змістами, складниками сутності взаємодії. Професійним обов'язком викладача $\epsilon$,прийняття” всіх майбутніх учителів і готовність будувати суб'єкт-суб'єктні взаємини з кожним із них.

2 - „Я як представник дорослого співтовариства - майбутні вчителі іноземних мов”. Викладач вступає у взаємини з майбутніми вчителями не тільки як самостійний суб'єкт і унікальна особистість, а й зі своєю професійною позицією як ,делегат” дорослого співтовариства: „емісар”, „посередник”, одна з цілей якого - допомогти майбутнім учителям пройти шлях до цього самого товариства і стати його членами. Тому у взаємодії з майбутніми вчителями викладач повинен виконувати цілком певні обов'язки, що накладаються на нього професією. При цьому кожен майбутній учитель будує стосунки 3 викладачем, з огляду на цю його особливість. Іноді цей підтип взаємин виявляється домінантним, у результаті чого „професійна маска представника педагогічного колективу” замінює суб'єктну сутність викладача. Суб'єкт-суб'єктні взаємини в такому випадку значною мірою погіршуються.

3 - ,Я як частина всієї спільності „викладач - майбутні вчителі іноземних мов" (Ми разом із майбутніми вчителями) - Вони”. Завдяки цьому типові стосунків викладач розглядає себе таким же членом групи, 
як i майбутніх учителів. Він убудований у складну систему внутрішньогрупових взаємин як один 3 обов'язкових (i навіть центральних) компонентів. Це особливо яскраво проявляється в ситуаціях суперництва або співпраці з іншими суб'єктами. Сприйняття викладачем себе як частини спільності „викладач - майбутні вчителі” може бути (залежно від ситуацій та рівня взаємин) і продуктивним, i деструктивним для становлення суб'єктності майбутнього вчителя іноземних мов.

Рівень організації суб'єкт-суб'єктної взаємодії в системі взаємовідносин „викладач - майбутні вчителі” - це динамічний показник. Суб'єктна позиція майбутнього вчителя при здійсненні суб'єкт-суб'єктної взаємодії в процесі вивчення іноземних мов передбачає самостійність, активність та готовність до вибору як усвідомлення відповідальності за результати і наслідки своєї діяльності, поведінки.

На думку О. Ліннік, при організації суб'єкт-суб'єктної взаємодії в процесі вивчення іноземних мов необхідно створювати умови для розвитку системи взаємовідносин „викладач - майбутні вчителі”. Такими умовами є:

1. Актуалізація i збагачення суб'єктного досвіду майбутніх учителів: звернення до їх раніше накопичених знань i вмінь; стимулювання майбутніх учителів до самостійного вибору й використання різних способів виконання завдання; створення ситуацій морального вибору; звернення до версій майбутніх учителів при пошуку варіантів вирішення пізнавальної задачі (проблеми); організація пізнання через переживання, актуалізацію чуттєвого досвіду.

2. Розвиток активності майбутніх учителів у навчальній діяльності: заохочення ініціативи; створення ситуацій вибору; організація творчої діяльності [Ліннік 2014: 126].

Успішність організації суб'єкт-суб'єктної взаємодії при вивченні іноземних мов забезпечується кількома важливими умовами. Назвемо їх:

- $\quad$ психолого-педагогічний супровід і майбутніх учителів, i викладачів;

- створення розвивального освітнього середовища, середовища прагнення до успіху, творчості, високих результатів, коли престижно якісно вчитися i працювати, дотримуючись моральноправової норми взаємодії викладачів і майбутніх учителів;

- $\quad$ спрямованість освітнього процесу на формування життєвої стратегії сталого розвитку особистості й індивідуальності в нестабільних умовах суспільства, на вирішення життєвих проблем;

- $\quad$ застосування технології навчання якісного нового рівня, що забезпечує успіх і високі досягнення в навчанні кожного майбутнього учителя. 
Згідно з Я. Фаріною, основні вимоги для успішної організації процесу суб' єкт-суб'єктної взаємодії викладача і майбутніх учителів при вивченні іноземних мов - це:

себе комфортно;

створювати атмосферу, у якій майбутній учитель відчуває

- $\quad$ стимулювати інтереси майбутніх учителів, розвивати їх бажання вчитися і тим самим робити реальними досягнуті ними успіхи в навчанні;

- зачіпати особистість майбутнього вчителя загалом i залучати до навчального процесу всі його почуття, емоції й відчуття;

- ураховувати потреби майбутнього вчителя та забезпечувати різноманіття або зміну прийомів і форм навчання;

- $\quad$ робити майбутнього вчителя активною дійовою особою в навчальному процесі, який усвідомлює, що вивчення іноземних мов пов'язане 3 його інтересами, а не із заданими викладачем прийомами i засобами навчання;

- $\quad$ створювати такі ситуації, у яких викладач не $\epsilon$ центральною фігурою, майбутні вчителя іноземних мов повинні стати рівноправними суб'єктами навчального процесу і активно спілкуватися один із одним, це змінює функції викладача, роблячи його спостерігачем, консультантом та учасником навчання;

- поступово навчити майбутнього вчителя працювати 3 іноземними мовами самостійно [Фаріна 2012: 8].

Показниками успішності суб'єкт-суб'єктної взаємодії при вивченні іноземних мов слід уважати прояв у майбутніх учителів таких особистісних характеристик, як: висока позитивна мотивація до пізнання, навчальної та суспільно значущої діяльності; висока усвідомлена активність майбутніх учителів у навчальній діяльності; висока соціальна активність, здатність до співпраці; самостійність й ініціативність; готовність до професійно-особистісного самовизначення; сформованість гуманістичних цінностей; задоволеність навчальною взаємодією. Ми вважаємо, що перерахований комплекс компетенцій забезпечує ефективність суб'єкт-суб'єктної взаємодії між викладачем і майбутніми учителями в процесі вивчення іноземних мов.

Здатність організувати конструктивну суб'єкт-суб'єктну взаємодію - один із значущих показників професійної компетентності викладача. Сучасна орієнтація освіти на формування компетенцій як готовності і здатності до організації суб'єкт-суб'єктної взаємодії в процесі вивчення іноземних мов передбачає створення дидактичних i психологічних умов, у яких майбутній учитель може проявити не тільки інтелектуальну та пізнавальну активність, але й особистісну і соціальну позицію, свою індивідуальність, виразити себе як суб'єкт навчання. Тому дуже важливий принцип роботи - принцип активності, коли в процесі 
вивчення іноземних мов залучається кожен майбутній учитель, стаючи при цьому активним учасником суб'єкт-суб'єктної взаємодії.

Таким чином, організація суб'єкт-суб'єктної взаємодії між викладачем i майбутніми учителями іноземних мов - процес безпосереднього або опосередкованого взаємовпливу людей один на одного, що передбачає їхню взаємну зумовленість загальними завданнями, інтересами, спільною діяльністю. Великий потенціал для формування суб'єкт-суб'єктної взаємодії викладача і майбутніх учителів закладений у спільне вивчення іноземних мов, коли обидві сторони виступають на рівних, а сама діяльність має творчий характер.

\section{Список використаної літератури}

1. Бойко А.М. Феномен „,суб'єкт-суб'єктні відносини” - стратегія подальшого розвитку педагогічної теорії і практики / А.М. Бойко // Гуманізація навчально-виховного процесу : зб. наук. пр. - Спецвип. 8. Ч. І. Словянськ : СДПУ, 2012. - С. 3 - 17. 2. Гончар О. В. Форми педагогічної взаємодії учасників навчального процесу в системі вищої школи України / О.В.Гончар // Педагогічні науки : зб. наук. пр. Полтава: ПНПУ, 2011. - С. 49 - 54. 3. Ліннік О.О. Майбутній учитель як суб'єкт педагогічної взаємодії: підготовка до співробітництва 3 молодшими школярами : монографія // О.О. Ліннік. - К. : Слово, 2014. 304 с. 4. Петухова Л. Є. Трисуб'єктна дидактика в моделі інноваційного розвитку освітніх систем / Л. С. Петухова // Педагогічні науки : зб. наук. пр. / ред. С. С. Барбіна. - Херсон : ХДУ, 2014 . - Вип. 65. - С. 74 - 80. 5. Пилюгина С.A. Формирование андрагогической субъектности учителя в системе постдипломного педагогического образования : дис. ... д-ра пед. наук : 13.00.08 / Пилюгина Светлана Анатольевна. Тольятти, 2014. - 387 с. 6. Сергиенко Е.А. Системно-субъектный подход : обоснование и перспектива / Е.А. Сергиенко // Психологический журн. - 2011. - Т. 32. - №1. - С. 120-131. 7. Фаріна Я.О. Суб'єктність студента як об'єкта освітнього впливу вищої школи : автореф. дис.. на здобуття наук. ступеня канд. соц. наук : спец. 22.00.04. „ Соціальні структури, соціальні інститути та спосіб життя" / Я.О. Фаріна. - Х., 2012. - 21 c. 8. Gough B. Subjectivity in Psychological Science : From Problem to Prospect / Brendan Gough, Anna Madill // Psychological Methods. - 2012. - Vol. 17. - № 3. - P. 374 - 384. 9. Li M. Cultural Subjectivity in Intercultural Communication / Mingxin Li // International Journal of Arts and Sciences. - 2010. - 3 (11). - P. 272 - 285.

\section{References}

1. Boiko A. (2012) Phenomen "subject-subjektni vinosyny" strategiya podalshogo rozvytku pedagogichnoii teorii i praktyky [The phenomenon of "subject-subject relations" - a strategy for the further development of pedagogical theory and practice] Gumanizatsiya navchalnovykhovnogo protsessu: zbirnyk naukovykh prats [Humanization of the 
educational process: Collection of scientific works] (pp. 3-17). Slovyansk [in Ukrainian]. 2. Farina Y. (2012) Subjektnist studenta yak objekta osvitniogo vplyvu vystschoii shkoly [Subjectivity of a student as an object of educational influence of higher school]. Kharkiv [in Ukrainian]. 3. Gonchar O. (2011) Formy pedagogichnoii vzaemodii uchasnykiv navchalnogo protsesu v systemi vystschoii shkoly Ukrainy [Forms of pedagogical interaction of participants in the educational process in the system of higher education of Ukraine] (pp. 4954). Poltava [in Ukrainian]. 4. Gough B. (2012) Subjectivity in Psychological Science: From Problem to Prospect / Brendan Gough, Anna Madill // Psychological Methods. Vol. 17. № 3. P. 374 - 384. 5. Li M. (2010) Cultural Subjectivity in Intercultural Communication / Mingxin Li // International Journal of Arts and Sciences. 3 (11). P. 272-285. 6. Linnik O. (2014) Maibutnii uchytel yak subject pedagogichnoii vzaemodii: pidgotovka do spivrobitnytstva $\mathrm{z}$ molodshymy shkoliaramy. Kyiv [in Ukrainian]. 7. Petukhova L. (2014) Trysubjektna dydaktyka $v$ modeli innovatsiinogo rozvytku osvitnikh system Three-point didactics in the model of innovative development of educational systems [Three-point didactics in the model of innovative development of educational systems] Pedagogichni nauky: zbirnyk naukovykh prats [Pedagogical sciences: Collection of scientific works] (pp. 74-80). Kherson [in Ukrainian]. 8. Pyliugina S. (2014) Formirovanie andragogicheskoy subiektnosti uchitelya $\mathrm{V}$ sisteme postdiplomnogo pedagogicheskogo obrazovaniya [Formation of the teacher's andragogical subjectivity in the system of postgraduate pedagogical education]. Tolyatti [in Russian]. 9. Sergienko E. (2011) Sistemno-subiektnyi podkhod: obosnovanie i perspektiva [System-Subject Approach: Rationale and Perspective] Psikhologicheskiy zhurnal [Psychological Journal] (pp. 120-131) [in Russian].

\section{Морозова М.В. Організація суб'скт-суб'сктної взаємодії в системі взасмовідносин „викладач - майбутні вчителі” в процесі вивчення іноземних мов}

У статті розглянуто процес організації суб'єкт-суб'єктної взаємодії в системі взаємовідносин „викладач - майбутні вчителі” в процесі вивчення іноземних мов. Охарактеризовано, що двохелементний характер системи „викладач - майбутні вчителі” передбачає два типи внутрішніх базових відносин, що сприяють організації суб'єкт-суб'єктної взаємодії в процесі вивчення іноземних мов. Було зазначено, що великий потенціал для формування суб'єкт-суб'єктної взаємодії викладача і майбутніх учителів закладений у спільне вивчення іноземних мов, коли обидві сторони виступають на рівних, а сама діяльність має творчий характер.

Ключові слова: суб'єкт-суб'єктна взаємодія, система взаємовідносин, викладач, майбутні вчителі, іноземні мови. 


\section{Морозова М.В. Организация субъект-субъектного взаимодействия в системе взаимоотношений «преподаватель - будущие учителя» в процессе изучения иностранных языков}

В статье рассмотрен процесс организации субъект-субъектного взаимодействия в системе взаимоотношений «преподаватель - будущие учителя» в процессе изучения иностранных языков Охарактеризовано, что двухэлементный характер системы «преподаватель - будущие учителя» предусматривает два типа внутренних базовых отношений, способствующих организации субъект-субъектного взаимодействия. Было отмечено, что процесс формирования субъект-субъектного взаимодействия преподавателя и будущих учителей заложен в совместном изучении иностранных языков, когда обе стороны выступают на равных, а сама деятельность имеет творческий характер.

Ключевые слова: субъект-субъектное взаимодействие, система взаимоотношений, преподаватель, будущие учителя, иностранные языки.

Morozova M.V. The organization of subject-subject interaction in the system of relations "lecturer - future teachers" in the process of learning foreign languages

The article deals with the process of organization of subject-subject interaction in the system of relations "lecturer - future teachers" in the process of learning foreign languages. It is determined that one of the most important conditions for an effective educational process is the interaction of its subjects. It is characterized that the two-element nature of the system "lecturer - future teachers" involves two types of internal basic relations that facilitate the organization of subject-subject interaction in the process of studying foreign languages. It is claimed that the principle of activity is a really important principle of work, that is future teacher should be involved in the process of studying foreign languages and therefore he will become an active participant in the subject-subject interaction. In fact, the organization of the subjectsubjective interaction between the lecturer and future teachers of foreign languages is the process of direct or indirect interaction of people with each other that implies their mutual influence with common tasks, interests and activities. It is noted that the process of encouraging subject-subject interaction of the lecturer and future teachers is applied in the co-study of foreign languages, when both sides act on equal terms and activity itself is creative.

Key words: subject-subjective interaction, system of relationships, lecturer, future teachers, foreign languages.

Стаття надійшла до редакції 27.03.2019 р.

Стаття прийнята до друку 28.03.2019 p.

Рецензент - д.пед.н, проф. ЛНУ імені

Тараса Шевченка Шехавцова С.О. 